\title{
EFFICIENCY OF SILICA NANOPARTICLES, TWO BIOINSECTICIDES, PEPPERMINT EXTRACT AND CHECED INSECTICIDE IN CONTROLLING COTTON LEAFWORM, Spodoptera littoralis BOISD. AND THEIR EFFECTS ON SOME ASSOCIATED NATURAL ENEMIES IN SUGAR BEET FIELDS \\ El-Samahy, M.F.M.; I.F. Khafagy and Asmaa M. A. El- Ghobary Plant Protect. Res. Inst. (PPRI), Agric. Res. Station (ARS), Sakha, Kafr El-Sheikh, Egypt, melsamahy75@yahoo.com
}

\begin{abstract}
This experiment was carried out at El-Riad region, Kafr El-Sheikh Governorate during two sugar beet successive seasons, 2013 and 2014. The aim of this study examined the efficiency of silica nanoparticles, bioinsecticides (Dipel $2 X$ and Biofly), peppermint extract and insecticide (Match 50\% EC) in controlling the cotton leafworm, Spodoptera littoralis (Boisd.) and their effects on some associated natural enemies in sugar beet. Results showed that the chemical insecticide (marshal) was the highest efficiency in controlling the cotton leafworm flowed by silica nanoparticles in high rate. Data showed also the extract of peppermint attractive the natural enemies to sugar beet filed and made moderate control the cotton leafworm.

Keywords: Cotton leafworm, sugar beet, silica nanoparticles, peppermint extract,
\end{abstract} natural enemies

\section{INTRODUCTION}

Sugar beet is an important and vital crop in Egypt, that was introduced to share sugar-cane in satisfying the requirements of sugar production in Egypt. This crop is subjected to infestation with its specific insects. However, in some cases, some common insect pests like the cotton leafworm, Spodoptera littoralis (Boisd.) (Lepidoptera: Noctuidae) could be more dangerous than specific ones. This occurs with the early sugar beet plantation sown in early September, because Ministry of Agriculture in Egypt encourages the farmers to widen the duration of sowing sugar beet to facility the work in factories of excluding sugar. Because the climate change that keeps the temperature relatively high throughout September, the insect can severely attack the seedlings of sugar beet causing large bare batches in the field and results in high economic losses (Shalaby, 2001; Helal, 2004; Abou El-Kassem, 2010; Bazazo, 2010 and El-Mahalawy, 2011).

The cotton leaf worm $S$. littoralis is considered as the major pest in a wide range of cultivation including cotton, corn, soybeans, peanuts and vegetables. In Egypt this pest is widely spread as well as in other Middle East countries in addition to temperate zones in Asia and Africa. This insect is very prolific pest whose female lay hundreds of eggs in egg masses, and the larvae pass through six instars in 15 to 23 days (Miyahara et al., 1971). 
Many insecticides have been tested against this pest Haas- Stapleton et al., (2003) the use of insecticides in agriculture field causes biological imbalance Yadav (2010) some new eco- friendly formulations pesticides became the target Cloyd and Bethke (2011) the pest resurgence again because it accepted resistance (Haas-Stapleton et al., 2003). The use of insecticides in agriculture field causes disturbance between beneficial insects and harmful insects (Yadav 2010). Zhang and Xiao-Zhen, (2010) and Cloyd and Bethke (2011), mentioned that, some new eco-friendly formulations pesticides became the target to control the pests.

The need for new safe method and effective insecticides became necessary nowadays after the increase of environmental pollution and insect resistance to chemical insecticides.

Nanotechnology employs nanoparticles that are made of inorganic or organic materials that are defined by having one or more dimensions in the order of $100 \mathrm{~nm}$ or less (El-bendary and El-Helaly, 2013).

The different types of silica have different specific surface area, particle size, drying loss, ignition loss and structure, which may affect their insecticidal activity. They are very light powders, are the most effective of all inert dusts and have an acute rat LD 50 of 3160 mg.kg ${ }^{-1}$ (Ebeling 1971).

The field application of silicon to susceptible rice and wheat cultivars increased crop tolerance and reduced pest infestation (El-Samahy, 2002; Basagli et al., 2003 and Ecole and Sampaio, 2004).

The new nanotechnology with materials having unique properties than their macroscopic or bulk counter parts, has promised applications in various fields. The essence of nanotechnology is the ability to work at the molecular level, atom by atom, to create large structures with fundamentally new molecular organization. The aim is to exploit these properties by gaining control of structures and devices at atomic, molecular, and supra molecular levels and to learn to efficiently manufacture and use these devices. Nanotechnology has provided new solutions to problems in plants and food science and offers new approaches to the rational selection of raw materials, or the processing of such materials to enhance the quality of plant products.

The application of silicon in crops provides a viable component of integrated management of insect pests and diseases because it leaves no pesticide residues in food or the environment and can be easily integrated with other pest management practices Laing et al., (2006). The field application of silicon to susceptible wheat cultivars increased crop resistance and reduced pest infestation Basagli et al., (2003); Ecole and Sampaio (2004).

Whiteley and Schnepf (1986) have shown that biological control of lepidopteran insect pests, affecting crop plants, is possible using Bacillus thuringiensis. Lepidopteran of the Noctuidae family, such as $S$. littoralis is susceptible to toxin of $B$. thuringiensis (Sanchis et al., 1994). Biopesticide products containing $B$. thuringiensis account for more than $20 \%$ of the biopesticides used worldwide (Sanchis et al., 1996). In Egypt, Salama and Foda (1982), Salama et al. (1982) and Salama et al. (1990) identified B. thuringiensis var. entomocidus as a highly effective strain against larvae of $S$. 
littoralis. El-Husseini et al. (2004) produced the conidiospores of Beauveria bassiana in two formulations for spraying and dusting applications in sugar beet fields. Populations of insect pests feeding by chewing all leaf tissue were considerably reduced by either technique, thus, $S$. littoralis population was reduced in sugar beet fields using this entomopathogenic fungus.

The aim of this study was to evaluate the efficiency of silica nanoparticles, two bioinsecticides, peppermint extract and insecticide in controlling the infestation with Spodoptera littoralis on sugar beet plants under field conditions and the side effect on associated predators.

\section{MATERIALS AND METHODS}

\section{Tested materials:}

Silica nanoparticles:

The silica nanoparticles was obtained from Nanotech Egypt Company Limited, Cairo, Egypt. It's size was $20 \mathrm{~nm}$ with a purity of $99.99 \%$. The Transmission Electronic Microscope (TEM) image of the silica nanoparticles is shown in Fig. 1. Five concentrations were used $(15,30,45,60$ and 75 g/fed.).

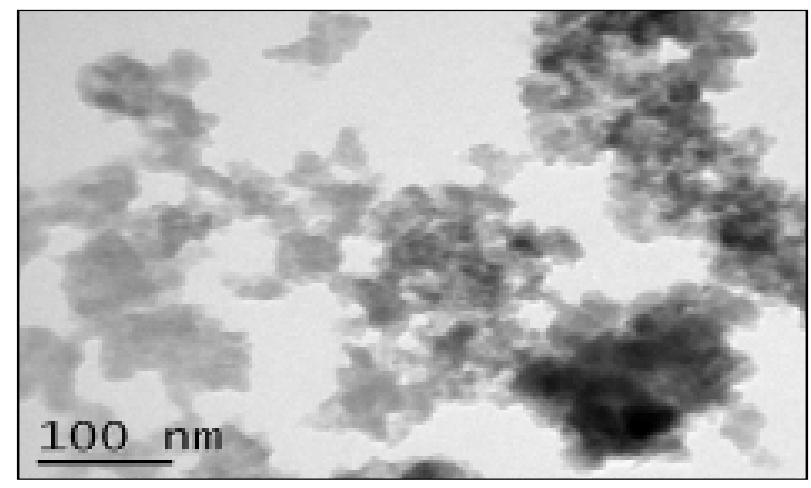

Fig. (1): The shape and size of silica nanoparticles.

\section{Bioinsecticides:}

Dipel 2X (Bacillus thuringiensis) at $300 \mathrm{~g} / \mathrm{fed}$. and biofly (Beauveria bassiana) at $300 \mathrm{ml} / \mathrm{fed}$.

Aromatic plant extract:

Peppermint Mentha piperita L. use by $150 \mathrm{~g} / \mathrm{fed}$. Insecticide:

Match $50 \%$ EC at $160 \mathrm{~cm}^{3} / \mathrm{fed}$.

Active Ingredient: Lufenuron

Structural formula 


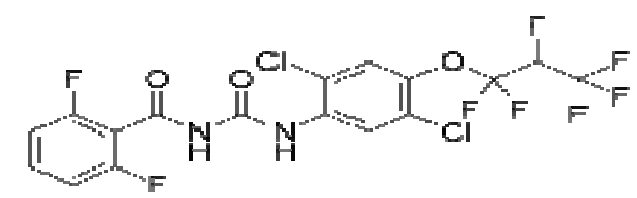

\section{Field experiment:}

Reduction percentage of Spodoptera littoralis (Boisd.) resulted from treatments:

This experiment was carried out at El-Riad region, Kafr El-Sheikh Governorate during two sugar beet successive seasons, 2013 and 2014. Experimental area was prepared, and sown with Pleno sugar beet cultivar on first of August every season. This date of sowing was selected to mimic the infestation of cotton leafworm, S. littoralis occurs in sugar beet fields sown on early August, when the temperature is high. All recommended cultural practices were applied along the growing seasons without insecticide applications.

The experimental area was divided into plots each of $1 / 100$ feddan, and the treatments were arranged in randomized complete blocks (RCB) with 4 replicates. When the larval population density reached minimum two larvae/plant started to examined five concentrations of silica nanoparticles, Dipel 2X ( $B$. thuringiensis), Biofly (B. bassiana), peppermint and Match. Each concentration from different treatments was sprayed on sugar beet plants in the open field, using knapsack sprayer $(20 \mathrm{~L}$ volume). Each sample from one replicate is 10 plants counted in the field. Larvae of $S$. littoralis were account before spraying and 2, 5, 7, and 15 days after treatments. The reductions in populations were calculated using Henderson and Tilton (1955) equation as follows =

Where:

$$
\% \text { Population reduction }=100 \times\left(1-\frac{T a \times C b}{T b \times C a}\right)
$$

Ta: Population in treated plots after treatment.

Tb: Population in treated plots before treatment.

Ca: Population in control after treatment.

$\mathrm{Cb}$ : Population in control before treatment.

\section{Reduction percentage of natural enemies resulted from treatments:}

Numbers of Chrysoperla carnea (larvae), Coccinella sp. (adults and larvae) and true spiders were counted per 10 sugar beet plants just before treatments, and then 2, 5, 7, 10 and 15 days after treatments. Also, the reduction in natural enemies were calculated with the same equation.

Statistical Analysis:

The obtained data were treated statistically according to the method of Duncan Multiple Range Test (Duncan, 1955).

\section{RESULTS AND DISCUSSION}

\section{1- Reduction in Spodoptera littoralis larvae:}

Data in Table (1) showed the reduction percentage of $S$. littoralis resulted from using silica nanoparticles (SiNPs) (five concentrations), 
biopesticides (Dipel 2X and Biofly) and insecticide (Match) during two successive seasons; 2013 and 2014 under sugar beet field conditions.

Table (1) showed results of treated sugar beet to control S. littoralis larvae with examined materials. After two days of treatments the insecticide (Match) was highly effective which recorded $80.50 \%$ reduction of larvae numbers followed by high rate of SiNPs (70 g/fed) followed by $60 \mathrm{~g} / \mathrm{fed} \mathrm{SiNPs} \mathrm{with} 70.00$ and $64.33 \%$ reduction, respectively. After one week match, SiNPs $(75 \mathrm{~g})$, peppermint and SiNPs $(60 \mathrm{~g})$ were recorded $84.75,69.75,61.75$ and $54.50 \%$ reduction in larvae numbers, respectively. While the lowest reductions were recorded in using SiNPs with low concentrations 15 and $30 \mathrm{~g} / \mathrm{fed}$.

Table (1): Reduction percentage of S. littoralis on sugar beet under field conditions at El-Riad region, Kafr El-Sheikh Governorate during 2013 season.

\begin{tabular}{|l|c|c|c|c|c|c|}
\hline \multirow{2}{*}{ Treatment } & \multirow{2}{*}{ Rate/fed. } & \multicolumn{5}{|c|}{ Days after treatment } \\
\cline { 3 - 7 } & & $\mathbf{2}$ & $\mathbf{5}$ & $\mathbf{7}$ & $\mathbf{1 0}$ & $\mathbf{1 5}$ \\
\hline \multirow{3}{*}{$\begin{array}{l}\text { Silica } \\
\text { nanoparticles }\end{array}$} & $15 \mathrm{~g}$ & 12.33 & 18.00 & 13.50 & 9.99 & 7.50 \\
\cline { 2 - 7 } & $30 \mathrm{~g}$ & 14.50 & 19.11 & 16.50 & 13.99 & 8.75 \\
\cline { 2 - 7 } & $45 \mathrm{~g}$ & 21.25 & 23.50 & 20.25 & 14.75 & 10.50 \\
\cline { 2 - 7 } & $60 \mathrm{~g}$ & 64.33 & 72.00 & 54.50 & 48.70 & 43.50 \\
\cline { 2 - 7 } & $75 \mathrm{~g}$ & 70.00 & 80.10 & 69.75 & 52.25 & 49.33 \\
\hline Peppermint & $150 \mathrm{~g}$ & 22.33 & 60.12 & 61.75 & 63.99 & 59.50 \\
\hline Dipel 2X & $300 \mathrm{~g}$ & 29.25 & 31.55 & 26.00 & 23.25 & 21.00 \\
\hline Biofly & $300 \mathrm{ml}$ & 27.75 & 24.75 & 40.90 & 15.33 & 14.00 \\
\hline Match & $160 \mathrm{ml}$ & 80.50 & 82.90 & 84.75 & 80.00 & 76.66 \\
\hline
\end{tabular}

Overall average (Fig. 2) of the population reduction of $S$. littoralis larvae under sugar beet field conditions. The statistical analysis showed significant differences between treatments.

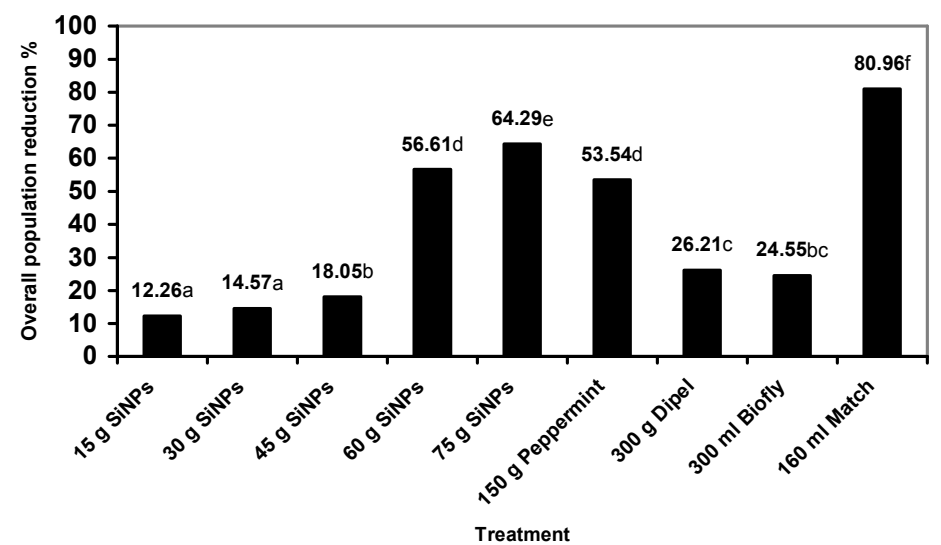

Fig. (2): Overall population reduction percentage of the cotton leafworm, S. littoralis numbers after treatments during 2013 seasons.

Means followed by a common letter are not significantly different at the $5 \%$ level by DMRT 
The highest obtained from using the chemical insecticide (match) $(80.96 \%)$ followed by SiNPs with high rate $(75 \mathrm{~g} / \mathrm{fed})$ which recorded $64.29 \%$ reduction. Data showed there are not significant differences among SiNPs (60 g/fed) and peppermint; and represented by 56.61 and $53.54 \%$ reduction, respectively. The bioinsecticides; dipel $2 X$ and biofly were showed 26.21 and $24.55 \%$ reduction, respectively without significantly differences.

During the second season 2014, results in Table (2) showed after two days of treatments the chemical insecticide (match) was recorded $82.33 \%$ reduction in $S$. littoralis larvae followed by SiNPs (75 and $60 \mathrm{~g} / \mathrm{fed}$.).

Table (2): Reduction percentage of S. littoralis on sugar beet under field conditions at El-Riad region, Kafr El-Sheikh Governorate during 2014 season.

\begin{tabular}{|l|c|c|c|c|c|c|}
\hline \multirow{2}{*}{ Treatment } & \multirow{2}{*}{ Rate/fed. } & \multicolumn{5}{|c|}{ Days after treatment } \\
\hline \multirow{4}{*}{$\begin{array}{l}\text { Silica } \\
\text { nanoparticles }\end{array}$} & $\mathbf{2}$ & $\mathbf{5}$ & $\mathbf{7}$ & $\mathbf{1 0}$ & $\mathbf{1 5}$ \\
\cline { 2 - 7 } & $30 \mathrm{~g}$ & 11.2 & 16.23 & 17.12 & 10.02 & 8.21 \\
\cline { 2 - 7 } & $45 \mathrm{~g}$ & 15.52 & 20.12 & 17.12 & 14.55 & 7.11 \\
\cline { 2 - 7 } & $60 \mathrm{~g}$ & 55.61 & 70.11 & 33.21 & 35.25 & 34.4 \\
\cline { 2 - 7 } & $75 \mathrm{~g}$ & 66.21 & 81.33 & 79.37 & 60.11 & 63.51 \\
\hline Peppermint & $150 \mathrm{~g}$ & 45.33 & 60.26 & 49.55 & 55.47 & 50.22 \\
\hline Dipel 2X & $300 \mathrm{~g}$ & 12.51 & 33.26 & 28.53 & 22.32 & 18.41 \\
\hline Biofly & $300 \mathrm{ml}$ & 18.43 & 26.41 & 33.67 & 12.36 & 10.44 \\
\hline Match & $160 \mathrm{ml}$ & 82.33 & 83.41 & 86.44 & 88.32 & 72.23 \\
\hline
\end{tabular}

Fig. (3) showed the overall average of population reduction percentage of the cotton bollworm, $S$. littoralis numbers after treatments. The statistical analysis showed significant differences between treatments.

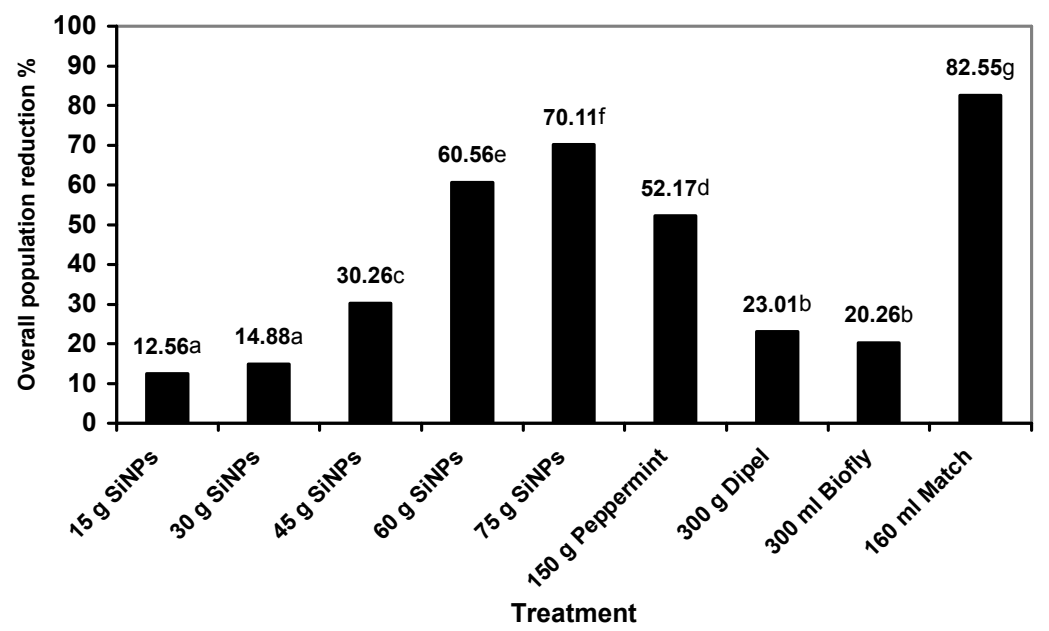


Fig. (3): Overall population reduction percentage of the cotton leafworm, S. littoralis numbers after treatments during 2014 seasons.

Means followed by a common letter are not significantly different at the $5 \%$ level by DMRT

While the insecticide (match) was highest effectiveness which recoded $82.55 \%$ reduction followed by SiNPs (75 and $60 \mathrm{~g} / \mathrm{fed}$.) with 70.11 and $60.56 \%$ reduction, respectively. The peppermint extract recoded $52.17 \%$ reduction. The bioinsecticides, dipel $2 \mathrm{X}$ and biofly were recorded 23.01 and $20.26 \%$ reduction, respectively without significantly.

Although the chemical insecticide (match) showed the highest effectiveness in controlling the cotton leafworm, $S$. littoralis in sugar beet field but the pest resurgence again because it accepted resistance (HaasStapleton et al., 2003). The silica nanoparticles enhanced the plant tolerance against cotton leafworm (Borei et al., 2014 and El-Samahy, 2015).

2- Reduction in some natural enemies associated with Spodoptera liitoralis (Boisd.):

Data in Table (3) showed the reduction percentage in some natural enemies associated with cotton leafworm, $S$. littoralis under sugar beet filed during two seasons; 2013 and 2014.

The chemical insecticide (match) showed the highest negative side effect on examined natural enemies; C. carnea, Coccinella spp. and true spiders at mean $80.64,84.13$ and $47.46 \%$ reduction, respectively during two seasons. The highest concentrations of SiNPs showed come in the second order in negative side effect which recorded 52.74, 40.13 and $37.28 \%$ reduction at $C$. carnea, Coccinella spp. and true spiders, respectively.

On the other hand peppermint showed positive effect while it increased the population of examined natural enemies C. carnea, Coccinella spp. and true spiders at $47.76,55.19$ and $21.88 \%$ increase.

Table (3): Reduction in some natural enemies associated with cotton leafworm, S. littoralis on sugar beet at El-Riad region, Kafr El-Sheikh Governorate during two seasons.

\begin{tabular}{|c|c|c|c|c|c|c|c|c|c|c|}
\hline \multirow[t]{2}{*}{ Treatment } & \multirow{2}{*}{$\begin{array}{l}\text { Ratel } \\
\text { fed. }\end{array}$} & \multicolumn{2}{|c|}{$\begin{array}{c}\text { Chrysoperla } \\
\text { carnea }\end{array}$} & \multirow{2}{*}{ Mean } & \multicolumn{2}{|c|}{$\begin{array}{c}\text { Coccinella } \\
\text { spp. }\end{array}$} & \multirow{2}{*}{ Mean } & \multicolumn{2}{|c|}{$\begin{array}{c}\text { True } \\
\text { spiders }\end{array}$} & \multirow{2}{*}{ Mean } \\
\hline & & 2013 & 2014 & & 2013 & 2014 & & \begin{tabular}{|l|}
2013 \\
\end{tabular} & 2014 & \\
\hline \multirow{5}{*}{$\begin{array}{l}\text { Silica } \\
\text { nanoparticles }\end{array}$} & $15 \mathrm{~g}$ & 26.36 & 27.12 & & 21.25 & 21.00 & 21.13 & \begin{tabular}{|l|l|}
3 & 20.66 \\
\end{tabular} & 0.00 & \\
\hline & $30 \mathrm{~g}$ & 31.15 & 33.0 & 32.08 & 27.33 & 26.12 & 26.73 & 324.25 & 207 & 24.00 \\
\hline & $45 \mathrm{~g}$ & 39.23 & 41.25 & 40.24 & 30.12 & 30.01 & 30.07 & 727.33 & 27.01 & 27.17 \\
\hline & $60 \mathrm{~g}$ & 45.45 & 46.00 & 45.73 & 36.14 & 35.14 & 35.64 & 431.25 & 31.00 & 31.13 \\
\hline & $75 \mathrm{~g}$ & 52.36 & 53.12 & 52.74 & 40.25 & 40.00 & 40.13 & \begin{tabular}{|l|l|}
37.45 \\
\end{tabular} & 37.11 & 37.28 \\
\hline Peppermint & $150 \mathrm{~g}$ & -47.33 & -48.19 & -47.76 & -55.35 & -55.03 & $3-55.19$ & \begin{tabular}{|l|l|}
9 & -22.00 \\
\end{tabular} & -21.75 & -21.88 \\
\hline Dipel 2X & $300 \mathrm{~g}$ & 40.12 & 41.33 & 40.73 & 45.25 & 44.75 & 45.00 & 28.50 & 28.25 & 28.38 \\
\hline Biofly & $300 \mathrm{ml}$ & 49.15 & 50.12 & 49.64 & 45.12 & 44.55 & 44.84 & 41.50 & 41.25 & 41.38 \\
\hline Match & $0 \mathrm{~m}$ & 80.13 & 81.1 & & & 84.00 & 3 & 47.7 & 47.15 & 47.46 \\
\hline
\end{tabular}


In conclusion, the chemical insecticide (match) showed the highest effect in controlling the cotton leafworm, S. littoralis on sugar beet field followed by SiNPs. Although the SiNPs come in the second order in

controlling $S$. littoralis after recommended insecticide (March) but results showed that it have negative effect on natural enemies so we can use these material in protect plants or the number of natural enemies were low. Results showed also, the plant extract (peppermint) was high attractive to natural enemies, so can use these extract to increase the number of natural enemies (Khafagy, 2011). The two bioinsecticides (Dipel 2X and Biofly) showed low effectiveness in controlling the cotton leafworm and reduce the number of associated predators.

\section{REFERENCES}

Abou-El-Kassem, A.B. (2010). Ecological and biological studies on some insects of sugar beet plants at Kafr El-Sheikh governorate. Ph.D. Thesis, Fac. Agric., Kafr El-Sheikh Univ.

Basagli, M.A.B.; J.C. Moraes; G.A. Carvalho; C.C. Ecole and C.R.R. de (2003). Goncalves-Gervasio. Effect of sodium silicate application on the resistance of wheat plants to the green aphid Schizaphis graminum (Rond.) (Hemiptera: Aphididae). Neootropical Entomology. 32 (4): 659663.

Bazazo, K.G.I. (2010). Studies on some insect pests and natural enemies in sugar beet fields at Kafr El-Sheikh region. Ph.D. Thesis, Fac. Agric., Tanta Univ. 162 pp.

Borei, H. A.; M. F. M. El-Samahy; Ola A. Galal, and A. F. Thabet (2014). The efficiency of silica nanoparticles in control cotton leafworm, Spodoptera littoralis Boisd. (Lepidoptera: Noctuidae) in soybean under laboratory conditions. Glob. J. Agric. Food Safety Sci., Vol.1 (2): 161-168.

Cloyd, R.A. and J.A. Bethke (2011). Impact of neonicotinoid insecticides on natural enemies in greenhouse and interiorscape environments. Pest Manage. Sci. 67(1): 3-9.

Duncan, D.B. (1955). Multiple Range and Multiple F. test. Biometrics, 11: 1-24.

Ebeling, W. (1971). Sportive dusts for pest control. Ann. Rev. Entomol. 16, 123-158.

Ecole C.C., M. Sampaio (2004). Silicon influence on the tritophic interaction: wheat pests, the greenbug Schizaphis graminum (Rondani) (Hemiptera: Aphididae), and its natural enemies, Chrysoperla externa (Hagen) (Neuroptera: Chrysopidae) and Aphidius colemani Viereck (Hymenoptera: Aphididae). Neotrop. Entomol. 33: 619-624.

El-Bendary, M. H. and A. A. El-Helaly (2013). First record nanotechnology in agricultural: Silica nanoparticles a potential new insecticide for pest control. App. Sci. Report. 4 (3), 241-246.

El-Husseini, M.M.; Shahira S. Marie; A. Mesbah; Amal A. El- Zoghby; Sahar S. Ali; Naglaa A.M. Omar; E.A. Agamy; H.E. Abou Bakr; Nada, M.S.; Tamer, Sherin; Kamal, Hannah M. and Ibrahim, A. (2004). Isolation, 
production and use of entomopathogenic fungi for controlling the sugar beet insect pests in Egypt. Proceedings of $1^{\text {st }}$ Arab Conference for Applied Biological Pest Control., Cairo, Egypt, 5-7 April. Egypt. J. of Biol. Pest Control., 14(1): 265-275.

El-Mahalawy, N.A. (2011). Ecological and biological studies on some sugar beet insects. M. Sc. Thesis, Fac. Agric., Tanta Univ.

El-Samahy, M.F.M. (2002). Studies rice stem borer, Chilo agamemnon Bles. M. Sc. Thesis, Fac. Agric. Kafr El-Sheikh, Tanta Univ., Egypt. 91 pp.

El-Samahy, M.F.M. (2015). Compare the efficacy of sodium metasilicate with silica nanoparticles against Spodoptera littoralis (Boisd.) in the laboratory. Egypt. J. Agric. Res., 93 (1) (B): 553-560.

Haas-Stapleton, E.J.; J.O Washburn and L.E. Volkmann (2003). Pathogenesis of Autographa californica M. nucleo polyhedron virus in fifth instar Spodoptera frugiperda. J. Gen. 84: 2033-2040.

Harper, S. (2010). New approaches needed to gauge safety of nanotechbased pesticides, Researchers Urge. Published In Physics \& Chemistry. 4(33): 2010-2012 .

Helal, R.M.Y. (2004). Ecological studies on the main insect pests of sugar beet plants and most common predators at Kafr El-Sheikh region. J. Agric. Sci., Mansoura Univ. 2004; 29 (2): 911-923.

Henderson, C. F. and E. W. Tilton (1955). Tests with acaricides against the brown wheat mite. J. Econ. Entomol., 48: 157-161.

Khafagy, I. F. I. (2011). Promising role of some aromatic plants for the management Bemisia tabaci. Ph.D. Thesis, Fac. Agric., Kafr ElSheikh, Kafr El-Sheikh Univ., 172 pp.

Laing, M.D.; M.C. Gatarayiha and A. Adandonon (2004). Silicon use for pest control in agriculture: A review Proc. S. Agri. Sug. Technol., Ass., 80, page 278 .

Matsumoto, S.; R.J. Christie; N. Nishiyama; K. Miyata and A. Ishii, (2009). Environment- responsive block copolymer micelles with a disulfide cross-linked core for enhanced siRNA delivery, Biomacromology, 10: 119-127.

Miyahara, Y.; T. Wakikado and A. Tanaka (1971). Seasonal changes in the number and size of the egg masses of Prodenia litura. Jap. J. Appl. Entomol. Zool. 15: 139-143.

Salama, H.S. and M.S. Foda (1982). A strain of Bacillus thuringiensis var. entomocidus with high potential activity on Spodoptera littoralis. J. Invertebr. Pathol., 39: 110-111.

Salama, H.S.; F.N. Zaki and A.R. Sharaby (1982). Effect of Bacillus thuringiensis Berl. on parasites and predators of the cotton leafworm Spodoptera littoralis (Boisd.). Z and J., Econno. Ent., 94: 498-504.

Salama, H.S.; F.N. Zaki; S.A. Salem and A. Shams El-Din (1990). Comparative effectiveness of Bacillus thuringiensis and Lannate against Spodoptera littoralis. J. Islamic Academy of Sci., 3(4): 325-329.

Sanchis, V.; J. Chaufaux and D. Pauron (1994). A comparison and ananlysis of the toxicity and receptor binding properties of Bacillus thuringiensis 
CrylC a. endotoxin on Spodoptera littoralis and Bombyx mori. FEBS Lett. 353: 259-263.

Sanchis, V.; H. Agaisse; J. Chaufaux and D. Lereclus (1996). Construction of new insectidal Bacillus thuringiensis recombinant strains by using the sporulation nondependent expression system of Cry IIIA and a site specific recommendation vector. J. Biotechnology, 48: 81-96.

Shalaby, G.A.M. (2001). Ecological studies on some important sugar beet pests and natural enemies and their control. Ph.D. Thesis, Fac. Agric., Kafr El-Sheikh, Tanta Univ., $141 \mathrm{pp}$.

Whiteley, H.R. and H.E. Schnepf (1986). The molecular biology of parasporal crystal body dormation in Bacillus thuringiensis. Ann. Rev. Microbial., 40: 549- 576

Yadav, S.K. (2010). Pesticide applications-threat to ecosystems. J. Hum. Ecol. 32(1): 37-45.

Zhang, S. and Y.E. Xiao-Zhen (2010). Impacts of chemical insecticides on extracellular protease and chitinase activities of Metarhizium anisopliae. J. Fujian College Forest. 4: 289-292.

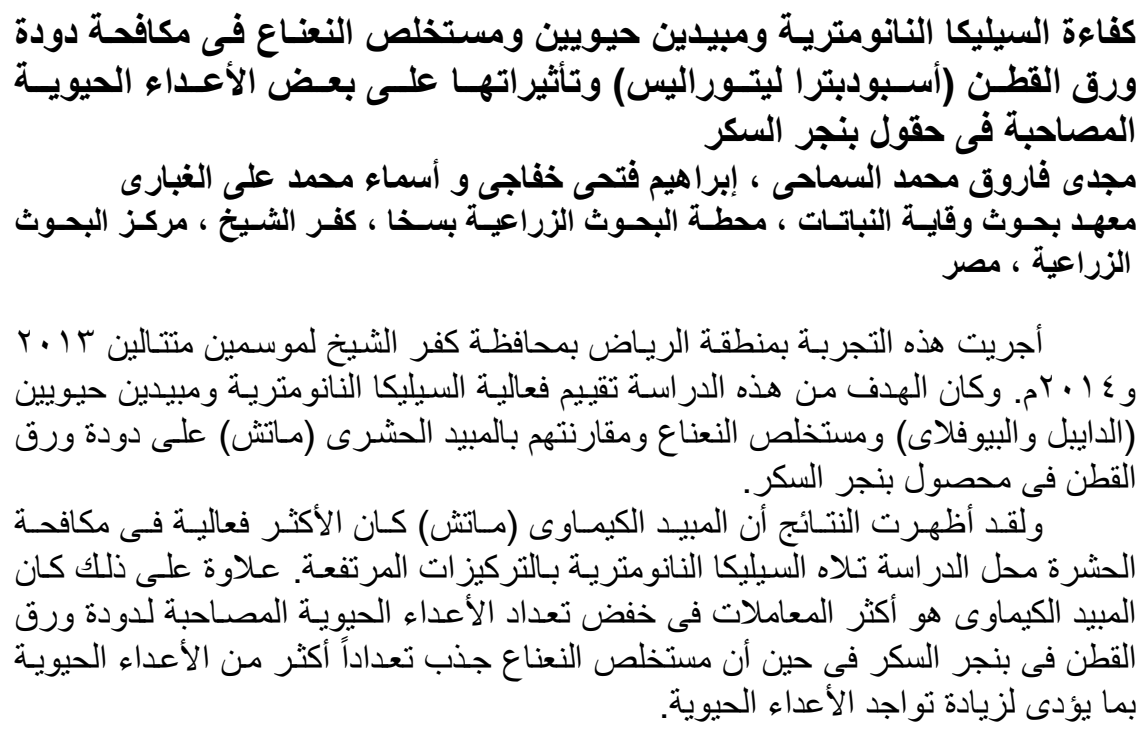

